\title{
Postprint of:
}

Alba, D. M., Casanovas-Vilar, I., Furió, M., García-Paredes, I., Angelone, C., Jovells-Vaqué, S., Luján, À. H., Almécija, S., \& Moyà-Solà, S. (2018). Can Pallars i Llobateres: A new hominoid-bearing locality from the late Miocene of the Vallès-Penedès Basin (NE Iberian Peninsula). Journal of Human Evolution, https://doi.org/10.1016/j.jhevol.2018.04.008 
1 Can Pallars i Llobateres: A new hominoid-bearing locality from the late Miocene of the Vallès-Penedès Basin (NE Iberian Peninsula)

3

4 David M. Alba ${ }^{a,}{ }^{*}$, Isaac Casanovas-Vilar ${ }^{a}$, Marc Furió ${ }^{\text {a, b }}$, Israel García-Paredes ${ }^{\text {c, a }}$, Chiara 5 Angelone ${ }^{d, a, ~ e}$, Sílvia Jovells-Vaqué ${ }^{\text {, Àngel H. Luján }}{ }^{\mathrm{f}, \mathrm{a}, \mathrm{g}}$, Sergio Almécija ${ }^{\mathrm{h}, \mathrm{a}}$, Salvador Moyà6 Solà $^{a, \mathrm{i}, \mathrm{j}}$

8 a Institut Català de Paleontologia Miquel Crusafont, Universitat Autònoma de Barcelona,

9 Edifici ICTA-ICP, c/ Columnes s/n, Campus de la UAB, 08193 Cerdanyola del Vallès, Barcelona, 10 Spain

$11{ }^{\mathrm{b}}$ Departament de Geologia, Universitat Autònoma de Barcelona, 08193 Bellaterra, Spain

12 ' Departamento de Paleontología, Facultad de Ciencias Geológicas, Universidad Complutense 13 de Madrid, c/ José Antonio Novais 2, 28040 Madrid, Spain

14 d Dipartimento di Scienze, Università Roma Tre, Largo San Leonardo Murialdo, 1 - 00146, 15 Roma, Italy

16 e Institute of Vertebrate Paleontology and Paleoanthropology, Chinese Academy of Sciences, 17 Xizhimen Wai Da Jie 142, Beijing 100044, China

$18{ }^{\mathrm{f}}$ Department of Geosciences, University of Fribourg, Chemin de Musée 6, 1700 Fribourg, 19 Switzerland

$20{ }^{\mathrm{g}}$ Department of Geological Sciences, Faculty of Science, Masaryk University, Kotlárská 2,

21 Brno, 611 37, Czech Republic

$22{ }^{\mathrm{h}}$ Center for the Advanced Study of Human Paleobiology, Department of Anthropology, The 23 George Washington University, Washington, DC 20052, USA 
'Institució Catalana de Recerca i Estudis Avançats (ICREA), Pg. Lluís Companys 23, 08010,

Barcelona, Spain

${ }^{j}$ Unitat d'Antropologia Biològica, Departament de Biologia Animal, Biologia Vegetal i

Ecologia, Universitat Autònoma de Barcelona, 08193 Cerdanyola del Vallès, Barcelona, Spain

28

${ }^{*}$ Corresponding author.

E-mail address: david.alba@icp.cat (D.M. Alba).

Keywords: Hominoidea; Dryopithecinae; Hispanopithecus; Teeth; Vallesian; Western Europe.

33

\section{Abstract}

In the Iberian Peninsula, Miocene apes (Hominoidea) are generally rare and mostly restricted to the Vallès-Penedès Basin. Here we report a new hominoid maxillary fragment with $\mathrm{M}^{2}$ from this basin. It was surface-collected in March 2017 from the site of Can Pallars i Llobateres (CPL, Sant Quirze del Vallès), where fossil apes had not been previously recorded. The locality of provenance (CPL-M), which has delivered no further fossil remains, is located very close (ca. $50 \mathrm{~m}$ ) to previously known CPL outcrops, and not very far (ca. $500 \mathrm{~m}$ in NW direction) from the classical hominoid-bearing locality of Can Poncic 1. Here we describe the new fossil and, based on the size and proportions of the $\mathrm{M}^{2}$, justify its taxonomic attribution to Hispanopithecus cf. laietanus, a species previously recorded from several Vallesian sites of the Vallès-Penedès Basin. Based on the associated mammal fauna from CPL, we also provide a biochronological dating and a paleoenvironmental reconstruction for the site. The associated fauna enables an unambiguous correlation to the Cricetulodon hartenbergeriProgonomys hispanicus interval local subzone, with an estimated age of 9.98-9.73 Ma (late 
Vallesian, MN10). Therefore, CPL-M is roughly coeval with the $H$. laietanus-bearing localities of Can Llobateres 1 and Can Feu 1, and minimally older than those of La Tarumba 1 and Can Llobateres 2. In contrast, CPL-M is younger than the early Vallesian (MN9) localities of Can

51 Poncic 1 (the type locality of Hispanopithecus crusafonti) as well as Polinyà 2 (Gabarró) and

52 Estació Depuradora d'Aigües Residuals-Riu Ripoll 13, where Hispanopithecus sp. is recorded.

53 The associated fauna from CPL indicates a densely forested and humid paleoenvironment

54 with nearby freshwater. This supports the view that Hispanopithecus might have been restricted to dense wetland forests soon before its extinction during the late Vallesian, due to progressive climatic deterioration. Coupled with the existence of other fossiliferous outcrops in the area, this find is most promising for the prospect of discovering additional fossil hominoid remains in the future.

59

\section{Introduction}

\subsection{The hominoid find from Can Pallars i Llobateres}

Miocene apes (Primates: Hominoidea) from Iberia are geographically restricted to

Catalonia (NE Iberian Peninsula), mostly coming from multiple sites in the Vallès-Penedès Basin (Alba, 2012), near Barcelona (Casanovas-Vilar et al., 2016a). Although several partial hominoid skeletons have been recovered there (Moyà-Solà and Köhler, 1996; Moyà-Solà et al., 2004; Alba, 2012; Alba et al., 2012b, 2015), hominoid remains are generally scarce and mostly consist of isolated specimens, being considered 'rare' or uncommon taxa that require

68 a large sampling effort to be adequately documented (e.g., Alba, 2012; Alba et al., 2017a).

69 This notwithstanding, sometimes hominoid finds are the result of fortunate circumstances (e.g., the partial skeleton of Hispanopithecus laietanus from Can Feu 1; Alba et al., 2012b). 
71 Here we report a maxillary fragment from the site of Can Pallars i Llobateres ${ }^{1}$ (CPL, Sant

72 Quirze del Vallès; Llenas Avellaneda, 1999; Furió et al., 2015; Casanovas-Vilar et al.,

$732016 a, b)$, which was surface-collected by J. Manel Méndez in March 2017. We describe and

74 figure this specimen, and compare it with previously known hominoid remains from the

75 Vallès-Penedès Basin, in order to justify its taxonomic assignment. Based on the study of the

76 unpublished associated vertebrate fauna, we further contextualize this find from both

77 chronological and paleoenvironmental viewpoints.

78

79

\subsection{Can Pallars i Llobateres}

80

CPL is located ca. 500-600 m NW from the site of Can Poncic ${ }^{2}$ (CP, Sant Quirze del Vallès;

81 Crusafont Pairó and Truyols Santonja, 1947; Figs. 1 and 2). The exact location of CP localities

82 (Crusafont Pairó and Golpe Posse, 1972; Golpe Posse, 1974) is uncertain due to the

83 insufficient published documentation (Crusafont Pairó and Truyols Santonja, 1947; Santafé

84 Llopis, 1978; Llenas i Avellaneda, 1996). However, based on published photographs

85 (Crusafont Pairó and Truyols Santonja, 1947), orthophotos from 1946 (ICGC, 2017), and

86 recent surveys (Alba and Almécija, 2017), CP can be confidently located within an area of

87 about 0.7 ha (Fig. 2). Hominoid remains were recovered at the locality of Can Poncic 1 (CP1)

88 from the early 1950s to the early 1970s (Crusafont Pairó, 1958; Crusafont Pairó and

89 Hürzeler, 1969; Crusafont-Pairó and Golpe-Posse, 1973; Moyà-Solà et al., 1990; Harrison,

90 1991; Golpe Posse, 1993; Alba, 2012; Alba et al., 2012a, 2013; Pérez de los Ríos et al., 2013).

91 CP1 is the type locality of the extinct great ape Hispanopithecus crusafonti (Begun, 1992),

\footnotetext{
1 Formerly spelled 'Can Pallàs de Llobateres' or 'Can Pallars de Llobateres.'

2 Formerly spelled 'Can Ponsic' or 'Can Ponsich.'
} 
otherwise only recorded from Teuleria del Firal (Begun, 1992; Alba, 2012) in the Seu d'Urgell Basin (Catalan Pyrenees).

The site of CPL was discovered in 1999, when urbanization works unearthed several Miocene large mammal remains within an area smaller than 1.5 ha (Fig. 2). These were excavated by a team from the former Institut de Paleontologia M. Crusafont in Sabadell (IPS), which also screen-washed some sediment samples. The exact provenance of most remains was not documented, but those subsequently surface-collected came from different spots (Fig. 2): CPL-A, CPL-B, CPL-P1 (=CPL-C), CPL-P3, CPL-P2, and CPL-P4. The more abundant small mammal material came from two consecutive stratigraphic horizons (CPL s.s. and CPL3) within the classical CPL area (M. Llenas Avellaneda, pers. comm. to D.M.A.; see also Llenas Avellaneda, 1999). Except for a provisional faunal list provided in the field report (Llenas Avellaneda, 1999) and a few subsequent emendations (Casanovas-Vilar et al., 2016b), the fossils from CPL remained mostly unpublished (but see Furió et al., 2015). The hominoid maxillary fragment described here was found embedded within a small sediment block of carbonated claystone in locality CPL-M (Alba et al., 2017b), within an uncultivated land parcel (Fig. 2) very close to the classical CPL outcrops (roughly equivalent to CPL-B). The find was immediately reported to the Archaeological and Paleontological Survey of the Generalitat de Catalunya, and is currently housed at the Institut Català de Paleontologia Miquel Crusafont (ICP) with catalog No. IPS102942.

\section{Materials and methods}

\subsection{Comparisons with other hominoids}

IPS102942 was compared with upper molars of other Vallès-Penedès dryopithecines (Begun et al., 1990; Begun, 1992; Golpe Posse, 1993; Moyà-Solà and Köhler, 1995, 1996; 
116 Moyà-Solà et al., 2004, 2009a,b; Alba, 2012; Alba et al., 2012a, 2013; Pérez de los Ríos et al.,

117 2013), with particular emphasis on those from CP1 (H. crusafonti) and Can Llobateres 1 and

1182 (CLL1 and CLL2, respectively; tooth locus identifications of $H$. laietanus from CLL1 after

119 Alba et al., 2012a). No upper molars are available from the other Vallès-Penedès localities

120 with H. laietanus, namely: La Tarumba 1 (LT1, type locality; Villalta Comella and Crusafont

121 Pairó, 1944; Golpe Posse, 1993), Polinyà 2 (Gabarró; PO2; Crusafont-Pairó and Golpe-Posse,

122 1973; Golpe Posse, 1993), Estació Depuradora d’Aigües Residuals-Riu Ripoll 13 (EDAR13;

123 Checa Soler and Rius Font, 2003) and Can Feu 1 (CF1; Alba et al., 2012b). All specimens were

124 measured with digital calipers to the nearest $0.1 \mathrm{~mm}$ by one of the authors (D.M.A.). The

125 following measurements were taken: $\mathrm{BL}$, buccolingual breadth (in $\mathrm{mm}$, taken both at the

126 mesial and the distal crown portions); MD, mesiodistal length (in $\mathrm{mm}$ ); and BLI,

127 breadth/length index (in \%, computed as maximum BL/MD×100). Dental terminology follows 128 Alba et al. (2013:Fig. 1).

\subsection{Associated fauna}

131 Large vertebrate remains from CPL are very scarce, including 52 specimens from CPL, CPL132 B, CPL-A, CPL-P1, CPL-P3 and CPL-P4-see Supplementary Online Material (SOM) S1 for 133 further details. The associated small mammal fauna is represented by a collection of 384 134 micromammal teeth from CPL and CPL3 (see SOM S1). All of the fossils are housed at the 135 ICP.

\subsection{Coordinates}

138 Geographic coordinates for paleontological localities are given in the Universal Transverse 139 Mercator (UTM) system, based on the European Terrestrial Reference System 1989 
140 (ETRS89). They were verified with the aid of topographic maps and orthophotos from the

141 web application VISSIR v3.26 of the Institut Cartogràfic i Geològic de Catalunya (ICGC, 2017).

143 3. Results

\section{$144 \quad 3.1$ Description of the hominoid maxilla}

145 IPS102942 is a left maxillary fragment (ca. $1.5 \times 2.0 \mathrm{~cm})$, still partially embedded in matrix, 146 that preserves an alveolus with broken roots and a socketed molar crown (Fig. 3A-C). The 147 specimen is poorly preserved, displaying multiple diagenetic cracks filled with sediment.

148 Given the poor preservation, little can be said about the comparative anatomy of the 149 maxilla, although the position of the preserved portion of the palatine process relative to the 150 alveolar margin suggests that the palate was deep.

151 Alba et al. (2017b) originally identified the near-complete, socketed tooth as $\mathrm{M}^{1}$, but 152 closer examination suggests it is $\mathrm{M}^{2}$. The missing crown, anterior to the molar crown, is 153 broken at or slightly below the cervix. The lingual root of this tooth, visible along most of its 154 length (because the maxillary bone lacks its lingual side), is mesiodistally broad and 155 resembles the single fused root of the socketed molar (which is slightly exposed below the 156 cervix). The cross-section of the roots close to the alveolar plane, in occlusal view, reveals 157 two buccal root canals, indicating that two distinct buccal roots were likely present, as it is 158 typical of hominoid upper molars. Although the presence of one or two buccal roots in 159 hominoid $\mathrm{P}^{4}$ is variable (Emoret and Kullmer, 2014), the aforementioned morphology of the 160 lingual root enables us to rule out an identification of the missing crown as a $\mathrm{P}^{4}$, meaning 161 that the missing crown is a molar. Given that the well-developed metacone and only 162 moderate distal tapering of the molar crown are not consistent with an $\mathrm{M}^{3}$, the socketed 163 molar must belong to an $\mathrm{M}^{2}$ ), and the missing crown was an $\mathrm{M}^{1}$. 
165 included the lingual and distal aspects of the hypocone, as well as most of the distal marginal 166 ridge-which nevertheless does not preclude taking reliable crown measurements. The 167 crown is quite worn, with extensive dentine exposure at the protocone and the preserved 168 portion of the hypocone. It displays a subrectangular to suboval and distally tapering 169 occlusal contour, being buccolingually broader $(B L=9.8 \mathrm{~mm})$ than mesiodistally long 170 (estimated $\mathrm{MD}=8.7 \mathrm{~mm} ; \mathrm{BLI}=112.6 \%$ ), and much broader on the mesial than on the distal $171(\mathrm{BL}=8.7 \mathrm{~mm})$ portions of the crown. The mesial contour of the crown is rather straight, 172 whereas the buccal and distal contours are convex, and the lingual contour is more clearly 173 biconvex. The crown displays quite vertical walls and is not particularly inflated toward its 174 base. There are four main cusps, the protocone being the most extensive, the hypocone 175 being the smallest, and the paracone and metacone being similar in size to one another 176 (although the former is somewhat higher). The buccal cusps are more mesially located than 177 the corresponding lingual cusps, and very peripheral. The hypocone is located on the 178 distolingual corner of the crown. Mesiobuccally from the protocone, at approximately the 179 crown midline behind the mesial marginal ridge, there is a small dentine exposure that 180 seemingly represents a completely worn protoconule located at the end of the similarly 181 worn preprotocrista. A short and slit-like mesial fovea is still discernible on the buccal moiety 182 of the crown in spite of wear. This fovea, which originally likely ran to the protoconule base, 183 is distally delimited by a rather straight and transverse hypoparacrista directed toward the 184 former protoconule. Two occlusal grooves can be still observed in spite of wear: a transverse 185 one, separating the bases of the protocone and the hypocone, and a more obliquely 186 oriented one, which runs from the buccal crown wall to the center of the trigon basin, separating the bases of the paracone and the metacone, and further transecting the merging 
point of the long postparacrista with the shorter premetacrista. The postmetacrista and the preparacrista progressively curve in a lingual direction until merging with the distal and mesial marginal ridges, respectively. A straight crista obliqua apparently linked the protocone with the metacone, although the postprotocrista portion has been completely obliterated by wear. Similarly, a somewhat developed hypocone-metacone crista might have crossed the distal fovea, although it has been largely obscured by wear and it is not possible

194 to ascertain whether it would have been continuous or not. No secondary enamel folds or wrinkling can be discerned, but this might be simply attributable to wear. No buccal or lingual cingular remnants are present.

\subsection{Comparisons with other Vallès-Penedès hominoids}

Compared with the available $\mathrm{M}^{1}$ and $\mathrm{M}^{2}$ sample of Vallès-Penedès hominoids, IPS102942

200 (Fig. 4a) fits well with the occlusal morphology of previously known specimens of

201 Hispanopithecus spp. (Fig. 4b-h, k-p). In particular, like the specimens of Hispanopithecus

202 (Alba et al., 2013; Pérez de los Ríos et al., 2013), IPS102942 differs from the upper molars of 203 the middle Miocene taxa-Dryopithecus (Fig. 4i), Pierolapithecus (Fig. 4j), and Anoiapithecus 204 (Fig. 4q-s) -in the more peripheralized cusps, the less bulging crown base, the apparently 205 lesser developed metacone-hypocone crista (even if blurred by wear in IPS102942), and the 206 more reduced cingula (although their development is variable in Hispanopithecus; Alba et 207 al., 2012b). Compared to the two species of Hispanopithecus from the Vallès-Penedès, the 208 slightly tapering occlusal profile of IPS102942 more closely resembles that of the $\mathrm{M}^{2}$ (Fig.

$2094 e-g, k, n-p)$ than the squarer profile of the $M^{1}$ (Fig. 4b-f,k-m), even though IPS102942 210 appears smaller and mesiodistally shorter than the previously recorded $\mathrm{M}^{2}$. The hypocone in 211 IPS102942 appears mesiodistally aligned with the protocone, as in the $\mathrm{M}^{2}$ of $H$. laietanus 
212 (Fig. 4f-h), whereas in the $M^{2}$ of H. crusafonti (Fig. 4k,n) the hypocone is more lingually

213 situated relative to the protocone, as in the $\mathrm{M}^{2}$ of Anoiapithecus (Fig. $4 \mathrm{r}, \mathrm{s}$ ).

214 With regard to metric comparisons, IPS102942 more closely resembles in both size and 215 proportions the smaller (presumably female) $\mathrm{M}^{1}$ of $H$. laietanus (Fig. 5a), being somewhat

216 smaller than all available $\mathrm{M}^{2}$ (Fig. 5b). Thus, the MD $(8.7 \mathrm{~mm})$ and $\mathrm{BL}(9.7 \mathrm{~mm})$ of IPS102942

217 fall somewhat below the known $\mathrm{M}^{2}$ size ranges of both $H$. laietanus ( $\mathrm{MD}$ mean $=10.18 \mathrm{~mm}$, 218 range $=8.8,11.2 \mathrm{~mm} ; \mathrm{BL}$ mean $=11.18 \mathrm{~mm}$, range $=10.0,11.6 \mathrm{~mm} ; n=5)$ and $H$. crusafonti $219($ MD mean $=10.10 \mathrm{~mm}$, range $=8.8,11.1 \mathrm{~mm} ; \mathrm{BL}$ mean $=11.50 \mathrm{~mm}$, range $=10.9,12.2 \mathrm{~mm}$; $220 n=4$; data from Alba et al., 2012a:Table 4). In turn, the BLI (112.6\%) of IPS102942 falls well 221 within the $\mathrm{M}^{2}$ range of both $\mathrm{H}$. laietanus (BLI mean $=110.54 \%$, range $=101.8 \%, 130.7 \% ; n=$ 222 5) and $H$. crusafonti $(B L I$ mean $=114.58 \%$, range $=105.4 \%, 127.3 \% ; n=4$; data from Alba et 223 al., 2012a:Table 4).

\section{Discussion}

\subsection{Taxonomic assignment}

Even before the erection of $H$. crusafonti by Begun (1992), the distinction of the CP1

228 hominoid sample at the species rank advocated by Begun et al. (1990) was already 229 controversial (Harrison, 1991; Ribot et al., 1996; Andrews et al., 1996). However, the 230 taxonomic validity of $H$. crusafonti has been subsequently supported by multiple researchers 231 (e.g., Cameron, 1999; Begun, 2002, 2009, 2015; Moyà-Solà et al., 2009a; Casanovas-Vilar et al., 2011; Pickford, 2012; Alba, 2012; Alba et al., 2012a). Alba et al. (2012a) concurred with Ribot et al. (1996) that the development of upper molar cingula is too variable to be 234 diagnostic (contra Begun, 1992, 2002), but confirmed that $H$. crusafonti tends to display 235 broader $\mathrm{M}^{1}$ and $\mathrm{M}^{2}$ than $H$. laietanus (Begun, 1992, 2002). However, based on available 
236 sample, such differences in occlusal proportions are only significant for the $\mathrm{M}^{1}$ (Alba et al.,

237 2012), so that this diagnostic criterion is not useful in the case of IPS102942, which

238 moreover falls in the extensive overlap zone between the two species. This notwithstanding,

239 an assignment to $H$. laietanus is supported by some subtleties of occlusal morphology

240 (hypocone position), for which $H$. crusafonti differs from $H$. laietanus and more closely

241 approaches the condition of Anoiapithecus (see Alba et al., 2013). Additional remains-the I $^{1}$

242 is particularly diagnostic (Begun, 1992; Alba et al., 2012a)-would be required to further

243 substantiate the attribution of IPS102942 to H. laietanus. Given that a single tooth is

244 available, we prefer to be cautious and provide a tentative assignment to this species, i.e., $H$.

245 cf. laietanus.

An updated faunal list from CPL is reported in Table 1 (see also SOM S2 and SOM Figs. S1-

S2). The presence of the three-toed horse Hippotherium conclusively demonstrates the

250 Vallesian age of CPL, being first recorded in the Vallès-Penedès Basin at 11.2 Ma (Garcés et

251 al., 1997, 2003; Agustí et al., 1997; Casanovas-Vilar et al., 2016a,b). This agrees with the

252 presence of the boselaphin antelope Miotragocerus aff. pannoniae sensu Moyà-Solà (1983)

253 and the lagomorph Prolagus crusafonti, which apparently replaced Miotragocerus

254 monnacensis (Moyà-Solà, 1983; Fuss et al., 2015) and Prolagus oeningensis (López Martínez, 255 2001; Angelone and Veitschegger, 2015), respectively, in the Vallesian. Rodents (Fig. 6) and 256 insectivores enable a more precise dating, the assemblage being dominated by Cricetulodon 257 sabadellensis, as in other Vallesian hominoid-bearing localities (CLL1 and CFE1; Casanovas258 Vilar et al., 2012). The presence of this species (instead of its putative ancestor, Cricetulodon 259 hartenbergeri), coupled with that of Democricetodon cf. nemoralis and Keramidomys 
pertesunatoi, and the absence of Progonomys hispanicus, indicates an unambiguous

261 correlation to the $C$. hartenbergeri - P. hispanicus interval local subzone of the Vallès-

262 Penedès Basin (Casanovas-Vilar et al., 2011, 2012, 2016a,b), with an estimated age of 9.98-

$2639.73 \mathrm{Ma}$ (Casanovas-Vilar et al., 2016a,b). This is consistent with the presence of Dinosorex

264 (which became extinct in the Vallès-Penedès Basin shortly after the MN9/MN10 transition;

265 Furió et al., 2015) and the co-occurrence between Lantanotherium sanmigueli and

266 Crusafontina endemica (characteristic of this subzone; Casanovas-Vilar et al., 2012).

267 CPL is therefore roughly coeval with CFE1 (same subzone; Casanovas-Vilar et al., 2012, 268 2016a,b) and CLL1 (with a magnetostratigraphically interpolated age of 9.76 Ma; Agustí et 269 al., 1996, updated by Casanovas-Vilar et al., 2016b after new chron boundaries in Hilgen et 270 al., 2012), where H. laietanus is also recorded (Crusafont Pairó, 1958, 1965; Crusafont Pairó 271 and Hürzeler, 1969; Crusafont-Pairó and Golpe-Posse, 1973; Begun et al., 1990; Moyà-Solà 272 et al., 1990; Harrison, 1991; Golpe Posse, 1993; Alba, 2012; Alba et al., 2012a,b). Because of 273 the absence of Progonomys, these localities have been classically correlated to MN9 (early 274 Vallesian; e.g., Agustí et al., 1996, 1997; Furió et al., 2015; Casanovas-Vilar et al., 2011, 2012, 275 2016a)-unlike the slightly younger locality of CLL2, which has also yielded remains of $H$. 276 laietanus (Moyà-Solà and Köhler, 1993, 1995, 1996; Almécija et al., 2007; Alba, 2012) and is 277 correlated to the $C$. sabadellensis + P. hispanicus concurrent range subzone (i.e., to MN10, 278 late Vallesian), with an interpolated age of 9.62 Ma (updated by Casanovas-Vilar et al., 279 2016b, after Agustí et al., 1996). Under the 'faunal' concept of MN units, CLL1 was even 280 selected by some authors (Fahlbusch, 1976; De Bruijn et al., 1992; Mein, 1999) as the 281 reference locality for MN9. However, Progonomys already commonly occurs in roughly 282 coeval sites from other Iberian basins (Hilgen et al., 2012; Van Dam et al., 2014; Casanovas283 Vilar et al., 2016b), with the lower boundary of MN10 being set at $9.98 \mathrm{Ma}$. Therefore, under 
a strictly biostratigraphic approach to MN units, MN10 would include the local subzone to which CPL, CLL1 and CFE1 are correlated (Casanovas-Vilar et al., 2016b).

The latest occurrence of $H$. laietanus corresponds to its type locality (LT1; Villalta Comella and Crusafont Pairó, 1944; Golpe Posse, 1993; Alba, 2012), correlated to the local Rotundomys montisrotundi lineage subzone (MN10) and with a magnetostratigraphically interpolated age of 9.57 Ma (Casanovas-Vilar et al., 2016a). In turn, the oldest possible occurrence of Hispanopithecus in the basin is documented at PO2 and EDAR13 (CrusafontPairó and Golpe-Posse, 1973; Golpe Posse, 1982, 1993; Moyà Solà et al. 1990; Harrison, 1991; Begun, 2002; Checa Soler and Rius Font, 2003; Alba, 2012). The former is correlated to MN9 in a strict sense (11.2-10.0 Ma; Casanovas-Vilar et al., 2011, 2016a), whereas EDAR13 is correlated to the $C$. hartenbergeri range subzone (10.3-9.98 Ma; Casanovas-Vilar et al., 2011, 2016a, b) and therefore older than CLL1. Even though the material from PO2 and EDAR13 has been classically assigned to H. laietanus (Crusafont-Pairó and Golpe-Posse, 1973; Golpe Posse, 1982, 1993; Moyà Solà et al., 1990; Harrison, 1991; Ribot et al., 1996; Checa Soler and Rius Font, 2003; Casanovas-Vilar et al., 2011; Alba, 2012), the scarce available remains are arguably undiagnostic at the species level: the female $C^{1}$ from $\mathrm{PO} 2$ was assigned to $H$. laietanus based on its similarities to those from CLL1 (Crusafont-Pairó and

301 Golpe-Posse, 1973; Golpe Posse, 1982, 1993), but this tooth type is unknown for $H$. crusafonti (e.g., Begun, 1992), and the same applies to the fragmentary manual phalanges from EDAR13 (Checa Soler and Rius Font, 2003), even if they resemble those of H. laietanus from CLL2 (Moyà-Solà and Köhler, 1996; Almécija et al., 2007). If the PO2 and EDAR13 remains are removed from the hypodigm of $H$. laietanus and 306 assigned to Hispanopithecus sp. (contra Alba, 2012), the known stratigraphic range of $H$. 307 laietanus is circumscribed to ca. 10 to $9.57 \mathrm{Ma}$. This is younger than CP1-the type locality of 
H. crusafonti (Begun, 1992; Alba, 2012; Alba et al., 2012a), correlated with the $C$. that $H$. laietanus might have postdated $H$. crusafonti. Unfortunately, the lack of diagnostic

311 remains from EDAR13 (roughly coeval to CP1) and dating uncertainties for PO2 do not allow

312 us to conclusively discard some overlap between the stratigraphic ranges of $H$. crusafonti

313 and the younger $H$. laietanus during the latest early Vallesian (MN9).

\subsection{Paleoenvironment}

Based on its postcranial morphology (Moyà-Solà and Köhler, 1996; Almécija et al., 2007, 2013, 2015; Alba et al., 2010, 2012b; Alba, 2012; Pina et al., 2012) and microwear analyses (Ungar, 1996; DeMiguel et al., 2014), H. laietanus can be considered an arboreal orthograde primate with specific adaptations to below-branch suspension and frugivory-thereby being indicative of densely forested environments, in agreement with the paleoenvironmental evidence provided by the CPL associated fauna (Table 1; SOM S2 and SOM Figs. S1-S2).

323 grassland habitat, given mesowear evidence that it displayed a wide dietary spectrum

324 (Kaiser et al., 2000; Kaiser, 2003). In contrast, the antelope Miotragocerus is considered a

325 browser (Merceron et al., 2007) and semiaquatic animal that inhabited closed and swampy

326 areas (Köhler, 1993). The latter is consistent with the nearby presence of freshwater, as

327 further indicated by the beaver Euroxenomys and the geoemydid turtle Ptychogaster.

328 Several small mammals are also indicative of a forested environment, including the

329 remarkable diversity of arboreal dormice, the presence of two eomyids, and the more

330 abundant cricetids Eumyarion and Anomalomys (Casanovas-Vilar and Agustí, 2007) - the

331 latter interpreted as a burrower that would have preferred moist soils (Casanovas-Vilar and 
Agustí, 2007). The diverse insectivore assemblage from CPL is similarly indicative of moist

333 and warm conditions, as further shown by the presence Dinosorex (a typical forest dweller;

334 Furió et al., 2015), Talpa (a burrower linked to constantly humid soils; Furió et al., 2011),

335 Plesiodimylus (a malacophagous taxon indicative of an abundant presence of gastropods;

336 Crespo et al., 2018), and Lantanotherium and Crusafontina (whose extant relatives are

337 restricted to the rainforests of southeastern Asia).

338 Most of the small mammal taxa apparently associated with humid forest environments

339 are not recorded in coeval sites from the inner Iberian Peninsula, which during the Vallesian

340 were typically characterized by more arid environments (Casanovas-Vilar and Agustí, 2007;

341 Casanovas-Vilar et al., 2008). This applies to most of the insectivores (with the exception of

342 Crusafontina; Furió et al., 2011) and multiple rodent taxa (the eomyids, most of the glirids,

343 and the cricetids Eumyarion and Anomalomys; Casanovas-Vilar and Agustí, 2007; Casanovas-

344 Vilar et al., 2008). This paleobiogeographical evidence suggests that, during the Vallesian,

345 Vallès-Penedès habitats were moister and more densely forested than other areas of the

346 Iberian Peninsula, thus being closer to those from France and Central Europe, as previously

347 noted for the late Aragonian (Casanovas-Vilar et al., 2008). Such environmental differences

348 would account for the observed geographical distribution of Miocene hominoids in the

349 Iberian Peninsula, being only recorded from the more humid and closed environments from

350 the Vallès-Penedès and Seu d’Urgell basins in NE Iberia (e.g., Alba, 2012).

351 Based on the associated fauna, the paleoenvironment of CPL can be inferred as a densely

352 forested and humid environment with nearby water, similar to that of CLL1. The latter has

353 further yielded plant remains, which together with the fauna allow us to reconstruct its

354 paleoenvironment as a very humid marshy area with nearby dense wetland forests with

355 some (sub)tropical plant elements (Marmi et al., 2012). The newly reported maxillary 
fragment of Hispanopithecus from CPL-M therefore supports the view that this taxon would have been restricted to forested humid habitats providing a year-round fruit supply (Marmi et al., 2012, and references therein). These habitats apparently persisted in the VallèsPenedès Basin until the early late Vallesian-even if they were progressively becoming more

360 fragmentary, due to an ongoing trend of climatic deterioration that ultimately presumably

361 led to their extinction (Agustí et al., 2003; Casanovas-Vilar et al., 2011; Marmi et al., 2012;

362 DeMiguel et al., 2014).

\section{Summary and conclusions}

We describe a new hominoid maxillary fragment with $\mathrm{M}^{2}$ recovered from a new locality from the site of $\mathrm{CPL}$, where Miocene apes had not been previously reported. Although CPL is relatively close $(500 \mathrm{~m})$ to the type locality of $H$. crusafonti $(10.30-9.98 \mathrm{Ma}$, MN9, early Vallesian), based on occlusal morphology the new find is tentatively assigned to $H$. cf. laietanus. The associated fauna from CPL further indicates a younger age (9.98-9.73 Ma), being roughly coeval with other Vallès-Penedès localities with H. laietanus (CLL1 and CFE1),

371 correlated to earliest MN10 (late Vallesian) on biostratigraphic grounds. Although some 372 temporal overlap between the two species cannot be completely ruled out, currently 373 available evidence is consistent with a replacement of $H$. crusafonti by $H$. laietanus close to 374 the MN9/MN10 transition (ca. 10.0 Ma). The associated fauna from CPL indicates a densely

375 forested and humid paleoenvironment with nearby freshwater (as in CLL1), thereby 376 strengthening the view that Hispanopithecus might have been restricted to dense wetland 377 forests soon before it went extinct in the late Vallesian. Given the existence of other 378 fossiliferous outcrops in CPL, the find reported here is most promising for the prospect of 379 finding additional fossil hominoid remains in this area. 


\section{Acknowledgments}

We are particularly indebted to Josep M. Méndez for finding the hominoid specimen described in this paper. We further thank Xènia Aymerich for the preparation of the specimen; Jordi Galindo, Marta S. March, Josep M. Méndez, and Josep M. Robles, for assistance during fieldwork and/or collection management; Manel Llenas for discussion on the site; and the Servei d'Arqueologia i Paleontologia of the Generalitat de Catalunya, for its collaboration. This work has been supported by the Spanish Ministerio de Economía, Industria y Competitividad and the European Regional Development Fund of the European Union (research contract RYC-2013-12470 to I.C.V.), the Spanish Agencia Estatal de Investigación and the European Regional Development Fund of the European Union (CGL2016-76431-P and CGL2017-82654-P, AEI/FEDER EU), the Generalitat de Catalunya (CERCA Programme), the Agència de Gestió d'Ajuts Universitaris i de Recerca of the

393 Generalitat de Catalunya (predoctoral grant 2018FI B1 00201 to S.J.V.), and the Departament 394 de Cultura of the Generalitat de Catalunya (fieldwork grant 2014/100609). À.H.L. 395 acknowledges two postdoctoral grants during the elaboration of this paper: one from the 396 Ministry of Education, Youth and Sport of the Czech Republic ("Study at Public Institutions of 397 Higher Education in the Czech Republic": 2016, No. MSMT-44726/2013), and another from 398 the University of Fribourg, Switzerland ("short stay for young researchers at Post-Doctoral 399 level" 2017). C.A. received support by a Visiting Scientist Fellowship under the Chinese 400 Academy of Sciences President's International Fellowship Initiative (CAS-PIFI) for 2017. 401 Finally, we thank Mike Plavcan, the Associate Editor and three anonymous reviewers for 402 helpful comments that helped us to improve a previous version of this paper. 
Agustí, J., Köhler, M., Moyà-Solà, S., Cabrera, L., Garcés, M., Parés, J.M., 1996. Can Llobateres: the pattern and timing of the Vallesian hominoid radiation reconsidered. Journal of Human Evolution 31, 143-155.

Agustí, J., Cabrera, L., Garcés, M., Parés, J.M., 1997. The Vallesian mammal succession in the Vallès-Penedès basin (northeast Spain): Paleomagnetic calibration and correlation with global events. Palaeogeography, Palaeoclimatology, Palaeoecology 133, 149-180.

411 Agustí, J., Sanz de Siria, A., Garcés, M., 2003. Explaining the end of the hominoid experiment 412 in Europe. Journal of Human Evolution 45, 145-153.

413 Alba, D.M., 2012. Fossil apes from the Vallès-Penedès Basin. Evolutionary Anthropology 21, $414 \quad 254-269$.

415 Alba, D.M., Almécija, S., 2017. Informe i memòria de la intervenció paleontològica de 416 prospecció a Can Poncic (Sant Quirze del Vallès, el Vallès Occidental). Unpublished field 417 report, Institut Català de Paleontologia Miquel Crusafont, Son Bou.

418 Alba, D.M., Almécija, S., Moyà-Solà, S., 2010. Locomotor inferences in Pierolapithecus and 419 Hispanopithecus: Reply to Deane and Begun (2008). Journal of Human Evolution 59, 143420149.

421 Alba, D.M., Casanovas-Vilar, I., Almécija, S., Robles, J.M., Arias-Martorell, J., Moyà-Solà, S., 422 2012a. New dental remains of Hispanopithecus laietanus (Primates: Hominidae) from Can 423 Llobateres 1 and the taxonomy of Late Miocene hominoids from the Vallès-Penedès Basin 424 (NE Iberian Peninsula). Journal of Human Evolution 63, 231-246.

425 Alba, D.M., Almécija, S., Casanovas-Vilar, I., Méndez, J.M., Moyà-Solà, S., 2012b. A partial 426 skeleton of Hispanopithecus laietanus from Can Feu and the mosaic evolution of crown427 hominoid positional behaviors. PLoS One 7, e39617. 
Alba, D. M., Fortuny, J., Pérez de los Ríos, M., Zanolli, C., Almécija, S., Casanovas-Vilar, I., 429 Robles, J.M., Moyà-Solà, S., 2013. New dental remains of Anoiapithecus and the first 430 appearance datum of hominoids in the Iberian Peninsula. Journal of Human Evolution 65, $431 \quad 573-584$.

Alba, D. M., Almécija, S., DeMiguel, D., Fortuny, J., Pérez de los Ríos, M., Pina, M., Robles, 433 J.M., Moyà-Solà, S., 2015. Miocene small-bodied ape from Eurasia sheds light on 434 hominoid evolution. Science 350, aab2625.

435 Alba, D.M., Casanovas-Vilar, I., Garcés, M., Robles, J.M., 2017a. Ten years in the dump: An 436 updated review of the Miocene primate-bearing localities from Abocador de Can Mata 437 (NE Iberian Peninsula). Journal of Human Evolution 102, 12-20.

Alba, D., Casanovas-Vilar, I., Moyà-Solà, S., 2017b. First record of the fossil great ape Hispanopithecus from the late Miocene site of Can Pallars i Llobateres (Sant Quirze del

Almécija, S., Alba, D.M., Moyà-Solà, S., Köhler, M., 2007. Orang-like manual adaptations in

443 the fossil hominoid Hispanopithecus laietanus: first steps towards great ape suspensory

444 behaviours. Proceedings of the Royal Society B 274, 2375-2384.

445 Almécija, S., Tallman, M., Alba, D.M., Pina, M., Moyà-Solà, S., Jungers, W.L., 2013. The femur 446 of Orrorin tugenensis exhibits morphometric affinities with both Miocene apes and later 447 hominins. Nature Communications 4, 2888.

448 Almécija, S., Smaers, J.B., Jungers, W.L., 2015. The evolution of human and ape hand 449 proportions. Nature Communications 6, 7717.

450 Andrews, P., Harrison, T., Delson, E., Bernor, R.L., Martin, L., 1996. Distribution and 451 biochronology of European and Southwest Asian Miocene catarrhines. In: Bernor, R.L., 
454 Angelone, C., Veitschegger, K., 2015. MN10 Prolagus (Ochotonidae, Lagomorpha) from 455 Austria: a new tile for the central European palaeobiogeography of the genus. Neues 456 Jahrbuch für Geologie und Paläontologie - Abhandlungen 275, 1-10.

457 Begun, D.R., 1992. Dryopithecus crusafonti sp. nov., a new Miocene hominoid species from 458 Can Ponsic (Northeastern Spain). American Journal of Physical Anthropology 87, 291-309. 459 Begun, D.R., 2002. European hominoids. In: Hartwig, W.C. (Ed.), The Primate Fossil Record. $460 \quad$ Cambridge University Press, Cambridge, pp. 339-368.

461 Begun, D.R., 2009. Dryopithecins, Darwin, de Bonis, and the European origin of the African apes and human clade. Geodiversitas 31, 789-816.

463 Begun, D.R., 2015. Fossil record of Miocene hominoids. In: Henke, W., Tattersall, I. (Eds.), 464 Handbook of Paleoanthropology. Second edition. Springer, Heidelberg, pp. 1261-1332. 465 Begun, D.R., Moyá-Sola, S., Kohler, M., 1990. New Miocene hominoid specimens from Can 466 Llobateres (Vallès Penedès, Spain) and their geological and paleoecological context. 467 Journal of Human Evolution 19, 255-268.

468 Bernor, R. L., Koufos, G.D., Woodburne, M.O., Fortelius, M., 1996. The evolutionary history 469 and biochronology of European and Southwest Asian Late Miocene and Pliocene 470 hipparionine horses. In: Bernor, R.L., Fahlbusch, V., Mittmann, H.-W. (Eds.), The Evolution 471 of Western Eurasian Neogene Faunas. Columbia University Press, New York, pp. 307-338. 472 Cameron, D.W., 1999. The single species hypothesis and Hispanopithecus fossils from the 473 Vallés Penedés Basin, Spain. Zeitschrift für Morphologie und Anthropologie 82, 159-186. 
474 Casanovas-Vilar, I., Agustí, J., 2007. Ecogeographical stability and climate forcing in the Late

475 Miocene (Vallesian) rodent record of Spain. Palaeogeography, Palaeoeclimatology,

$476 \quad$ Palaeoecology 248, 169-189.

477 Casanovas-Vilar, I., Alba, D.M., Moyà-Solà, S., Galindo, J., Cabrera, L., Garcés, M., Furió, M.,

478 Robles, J.M., Köhler, M., Angelone, C., 2008. Biochronological, taphonomical and

479 paleoenvironmental background of the fossil great ape Pierolapithecus catalaunicus

480 (Primates, Hominidae). Journal of Human Evolution 55, 589-603.

481 Casanovas-Vilar, I., Alba, D.M., Garcés, M., Robles, J.M., Moyà-Solà, S., 2011. Updated

482 chronology for the Miocene hominoid radiation in Western Eurasia. Proceedings of the

$483 \quad$ National Academy of Sciences USA 108, 5554-5559.

484 Casanovas-Vilar, I., Furió, M., Alba, D.M., Moyà-Solà, S., Méndez, J.M., 2012. Rodents and

485 insectivores from the hominoid-bearing site of Can Feu (Vallès-Penedès Basin, Catalonia,

486 Spain). Journal of Vertebrate Paleontology 32, 225-230.

487 Casanovas-Vilar, I., Madern, A., Alba, D.M., Cabrera, L., García-Paredes, I., Van den Hoek

488 Ostende, L.W., DeMiguel, D., Robles, J.M., Furió, M., Van Dam, J., Garcés, M., Angelone,

489 C., Moyà-Solà, S., 2016a. The Miocene mammal record of the Vallès-Penedès Basin

$490 \quad$ (Catalonia). Comptes Rendus Palevol 15, 791-812.

491 Casanovas-Vilar, I., Garcés, M., Van Dam, J., García-Paredes, I., Robles, J.M., Alba, D.M., 492 2016b. An updated biostratigraphy for the late Aragonian and the Vallesian of the Vallès-

493 Penedès Basin (Catalonia). Geologica Acta 14, 195-217.

494 Checa Soler, L., Rius Font, L., 2003. Intervenció paleontològica a l'EDAR Sabadell-Riu Ripoll

495 (Can Llobateres, Sabadell, Vallès Occidental). Tribuna d'Arqueologia 1999-2000, 7-22. 
Crespo, V.D., Furió, M., Ruiz-Sánchez, F.J., Montoya, P., 2018. A new species of Plesiodimylus

497 (Dimylidae, Eulipotyphla, Mammalia) from the Early Miocene of Spain. Historical Biology

$498 \quad 30,360-371$.

499 Crusafont Pairó, M., 1958. Nuevo hallazgo del póngido vallesiense Hispanopithecus. Boletín

500 Informativo de las Actividades Europeas en Paleontología de Vertebrados 13-14, 37-44.

501 Crusafont Pairó, M., 1965. El desarrollo de los caninos en algunos Driopitécidos del

502 Vallesiense en Cataluña. Noticias y Comunicaciones del Instituto Geológico y Minero de 503 España 80, 179-192.

504 Crusafont Pairó, M., Golpe Posse, J.M., 1972. Los yacimientos de mamíferos fósiles del 505 Vallès. Boletín Informativo del Instituto Provincial de Paleontología de Sabadell 4, 20-24.

506 Crusafont-Pairó, M., Golpe-Posse, J.M., 1973. New pongids from the Miocene of Vallès 507 Penedès Basin (Catalonia, Spain). Journal of Human Evolution 2, 17-23.

508 Crusafont Pairó, M., Hürzeler, J., 1969. Catálogo comentado de los póngidos fósiles de 509 España. Acta Geológica Hispánica 4, 44-48.

510 Crusafont Pairó, M., Truyols Santonja, J., 1947. Sobre el descubrimiento de un nuevo 511 yacimiento del meótico en el Vallés. Boletín del Instituto Geológico y Minero de España $512 \quad 60,71-107$.

513 De Bruijn, H., Daams, R., Daxner-Höck, G., Fahlbusch, V., Ginsburg, L., Mein, P., Morales, J., 514 1992. Report of the RCMNS working group on fossil mammals, Reisenburg 1990.

$515 \quad$ Newsletters on Stratigraphy 26, 65-118.

516 DeMiguel, D., Alba, D.M., Moyà-Solà, S., 2014. Dietary specialization during the evolution of 517 Western Eurasian hominoids and the extinction of European great apes. PLoS One 9, 518 e97442. 
519 Emonet, E.-G., Kullmer, O., 2014. Variability in premolar and molar root number in a modern 520 population of Pan troglodytes verus. Anatomical Record 297, 1927-1934.

521 Fahlbusch, V., 1976. Report on the International Symposium on mammalian stratigraphy of 522 the European Tertiary (München, April 11-14, 1975). Newsletters on Stratigraphy 5, 160$523 \quad 167$.

524 Furió, M., Casanovas-Vilar, I., van den Hoek Ostende, L., 2011. Predictable structure of 525 Miocene insectivore (Lipotyphla) faunas in Western Europe along a latitudinal gradient. Palaeogeography, Palaeoclimatology, Palaeoecology 304, 219-229.

527 Furió, M., Prieto, J., Van den Hoek Ostende, L., 2015. Three million years of “Terror-Shrew" 528 (Dinosorex, Eulipotyphla, Mammalia) in the Miocene of the Vallès-Penedès Basin 529 (Barcelona, Spain). Comptes Rendus Palevol 14, 111-124.

530 Fuss, J., Prieto, J., Böhme, M., 2015. Revision of the boselaphin bovid Miotragocerus 531 monacensis Stromer, 1928 (Mammalia, Bovidae) at the Middle to Late Miocene transition 532 in Central Europe. Neues Jahrbuch für Geologie und Paläontologie - Abhandlungen 276, $533 \quad 229-265$.

534 Garcés, M., Cabrera, L., Agustí, J., Parés, J.M., 1997. Old World first appearance datum of 535 "Hipparion" horses: Late Miocene large-mammal dispersal and global events. Geology 25, $536 \quad 19-22$.

537 Garcés, M., Krijgsman, W., Peláez-Campomanes, P., Álvarez Sierra, M.A., Daams, R., 2003. 538 Hipparion dispersal in Europe: magnetostratigraphic constraints from the Daroca area 539 (Spain). Coloquios de Paleontología Vol. Ext. 1, 171-178.

540 Golpe-Posse, J.M., 1974. Faunas de yacimientos con suiformes en el Terciario español. 541 Paleontología y Evolución 8, 1-87. 
Golpe Posse, J.M., 1993. Los Hispanopitecos (Primates, Pongidae) de los yacimientos del

543 Vallès-Penedès (Cataluña, España). II: Descripción del material existente en el Instituto de

$544 \quad$ Paleontología de Sabadell. Paleontologia i Evolució 26-27, 151-224.

545 Harrison, T., 1991. Some observations on the Miocene hominoids from Spain. Journal of $546 \quad$ Human Evolution 19, 515-520.

547 Hilgen, F.J., Lourens, L.J., Van Dam, J.A., 2012. The Neogene period. In: Gradstein, F.M., Ogg, 548 J.G., Schmitz, M.D., Ogg, G.M. (Eds.), The Geologic Time Scale 2012, Vol. 2. Elsevier, $549 \quad$ Amsterdam, pp. 923-978.

550 Institut Cartogràfic i Geològic de Catalunya (ICGC), 2017. VISSIR v3.26 (VISor del Servidor 551 d'Imatges Ràster). Generalitat de Catalunya, http://www.icc.cat/vissir3/ [last accessed $552 \quad$ August 27, 2017]

553 International Commission on Zoological Nomenclature (ICZN), 1999. International Code of 554 Zoological Nomenclature. Fourth Edition. The International Trust for Zoological $555 \quad$ Nomenclature, London.

556 Kaiser, T.M., 2003. The dietary regimes of two contemporaneous populations of 557 Hippotherium primigenium (Perissodactyla, Equidae) from the Vallesian (Upper Miocene) 558 of Southern Germany. Palaeogeography, Palaeoclimatology, Palaeoecology 198, 381-402. 559 Kaiser, T.M., Solounias, N., Fortelius, M., Bernor, R.L., Schrenk, F., 2000. Tooth mesowear 560 analysis on Hippotherium primigenium from the Vallesian Dinotheriensande (Germany) $561 \quad$ A blind test study. Carolinea 58, 103-114.

562 Köhler, M., 1993. Skeleton and habitat of recent and fossil ruminants. Münchner 563 Geowissenschaftliche Abhandlungen A 25, 1-88. 
564 Llenas i Avellaneda, M., 1996. Datació per mètodes paleontològics amb micromamífers dels 565 materials neògens que afloren a l'àmbit dels fulls N. 392-4-3, 392-4-4 i 420-3-1 a escala 566 1/10.000. Unpublished report, Institut Cartogràfic de Catalunya, Sabadell.

567 Llenas Avellaneda, M., 1999. Memòria de l'excavació d'urgència a l'urbanització de Can 568 Pallàs (Sant Quirze del Vallès). Unpublished field report, Sabadell.

569 López Martínez, N., 2001. Paleobiogeographical history of Prolagus, an European ochotonid $570 \quad$ (Lagomorpha). Lynx 32, 215-231.

571 Marmi, J., Casanovas-Vilar, I., Robles, J.M., Moyà-Solà, S., Alba, D.M., 2012. The

572 paleoenvironment of Hispanopithecus laietanus as revealed by paleobotanical evidence 573 from the Late Miocene of Can Llobateres 1 (Catalonia, Spain). Journal of Human Evolution $574 \quad 62,412-423$.

575 Mein, P., 1999. European Miocene mammal biochronology. In: Rössner, G.E., Heissig, K. 576 (Eds.), The Miocene Land Mammals of Europe. Verlag Dr. Friedrich Pfeil, München, pp. $577 \quad 25-38$. brancoi at Rudabánya, Hungary: evidence from dental meso- and micro-wear analyses of large vegetarian mammals. Journal of Human Evolution 53, 331-349.

581 Moyà-Solà, S., 1983. Los Boselaphini (Bovidae Mammalia) del Neógeno de la Península 582 Ibérica. Universitat Autònoma de Barcelona, Publicaciones de Geología. evolution of great apes. Nature 365, 543-545. 
Moyà-Solà, S., Köhler, M., 1996. A Dryopithecus skeleton and the origins of great-ape locomotion. Nature 379, 156-159.

Moyà Solà, S., Pons Moyà, J., Köhler, M., 1990. Primates catarrinos (Mammalia) del Neógeno de la península Ibérica. Paleontologia i Evolució 23, 41-45.

Moyà-Solà, S., Köhler, M., Alba, D.M., Casanovas-Vilar, I., Galindo, J., 2004. Pierolapithecus catalaunicus, a new Middle Miocene great ape from Spain. Science 306, 1339-1344.

Moyà-Solà, S., Köhler, M., Alba, D.M., Casanovas-Vilar, I., Galindo, J., Robles, J.M., Cabrera, L., Garcés, M., Almécija, S., Beamud, E., 2009a. First partial face and upper dentition of the Middle Miocene hominoid Dryopithecus fontani from Abocador de Can Mata (VallèsPenedès Basin, Catalonia, NE Spain): taxonomic and phylogenetic implications. American Journal of Physical Anthropology 139, 126-145.

Moyà-Solà, S., Alba, D.M., Almécija, S., Casanovas-Vilar, I., Köhler, M., De Esteban-Trivigno, S., Robles, J.M., Galindo, J., Fortuny, J., 2009b. A unique Middle Miocene European hominoid and the origins of the great ape and human clade. Proceedings of the National Academy of Sciences USA 106, 9601-9606.

Pérez de los Ríos, M., Alba, D.M., Moyà-Solà, S., 2013. Taxonomic attribution of the La Grive hominoid teeth. American Journal of Physical Anthropology 151, 558-565.

Pickford, M., 2012. Hominoids from Neuhausen and other Bohnerz localities, Swabian Alb, Germany: evidence for a high diversity of apes in the Late Miocene of Germany. Estudios Geológicos 68, 113-147.

Pina, M., Alba, D.M., Almécija, S., Fortuny, J., Moyà-Solà, S., 2012. Brief communication: Paleobiological inferences on the locomotor repertoire of extinct hominoids based on femoral neck cortical thickness: The fossil great ape Hispanopithecus laietanus as a testcase study. American Journal of Physical Anthropology 149, 142-148. 
Ribot, F., Gibert, J., Harrison, T., 1996. A reinterpretation of the taxonomy of Dryopithecus

613 from Vallès-Penedès, Catalonia (Spain). Journal of Human Evolution 31, 129-141.

614 Santafé Llopis, J.V., 1978. Rinocerótidos fósiles de España. PhD. dissertation, Universidad de 615 Barcelona.

616 Ungar, P.S., 1996. Dental microwear of European Miocene catarrhines: evidence for diets 617 and tooth use. Journal of Human Evolution 31, 335-366.

618 Van Dam, J. A., Krijgsman, W., Abels, H.A., Álvarez-Sierra, M.Á., García-Paredes, I., López-

619 Guerrero, P., Peláez-Campomanes, P., Ventra, D., 2014. Updated chronology for middle to 620 late Miocene mammal sites of the Daroca area (Calatayud-Montalbán Basin, Spain).

621 Geobios 47, 325-334.

622 Villalta Comella, J.F. de, Crusafont Pairó, M., 1944. Dos nuevos antropomorfos del Mioceno 623 español y su situación dentro de la moderna sistemática de los símidos. Noticias y 624 Comunicaciones del Instituto Geológico y Minero de España 13, 91-139.

625

\section{Figure captions}

Figure 1. Geological map of the Vallès sector of the Vallès-Penedès Basin (NE Iberian

Peninsula), indicating the location of all the Vallesian localities that have delivered fossil remains of Hispanopithecus spp. Abbreviations (municipalities indicated within brackets):

CFE1 = Can Feu 1 [Sant Quirze del Vallès]; CLL1 = Can Llobateres 1 [Sabadell]; CLL2 = Can Llobateres 2 [Sabadell]; CP1 = Can Poncic 1 [Sant Quirze del Vallès]; CPL-M = Can Pallars i 
636 Figure 2. Aerial photograph showing various fossiliferous outcrops from Can Pallars i

637 Llobateres (CPL) and the approximate location of the classical site of Can Poncic (CP). Dotted

638 white rectangles denote loosely defined sites, whereas red asterisks denote the exact

639 location of paleontological localities. The location of the Can Poncic farmhouse and other

640 local toponyms are also indicated. North is toward the top. Coordinates are indicated below

641 (for details on the system of geographical coordinates used, please see the Materials and

642 methods). Legend: $\mathrm{CPL}=$ Can Pallars i Llobateres (central coordinates: $31 \mathrm{~N} 421450 \mathrm{E}-$

$6434598750 \mathrm{~N}$, including CPL-A and CPL3); CPL-M (=CPL-B) = Location of the hominoid find by

644 Méndez (31N 421380 E - 4598702 N); CPL-P2 = Spot 2 of CPL (31N 421610 E - 4598607 N);

645 CPL-P3 = Spot 3 of CPL (31N 421423 E - 4598424 N); CPL-P4 = Spot 4 of CPL (31N 421672 E -

6464598609 N); CP = Can Poncic (approximate coordinates 31N $421900-4598475)$. Other CPL

647 localities not depicted in the figure include CPL-B (31N $421410 \mathrm{E}-4598675 \mathrm{~N})$ and CPL-P1

648 (=CPL-C; 31N $421470 \mathrm{E}-4598485 \mathrm{~N}$ ). Figure modified from base orthophotos downloaded

649 from VISSIR v3.26 (ICGC, 2017: sheets 286-119 and 287-119, scale 1:2500), CInstitut

650 Cartogràfic i Geològic de Catalunya, with permission allowed by licence Creative Commons

651 (CC) - Attribution 4.0 International (CC BY 4.0; see http://www.icgc.cat/Ajuda/Avis-legal for

652 the reuse policies allowed for ICGC web contents).

653

654 Figure 3. Left maxillary fragment with $\mathrm{M}^{2}$ (IPS102942) of Hispanopithecus cf. laietanus from

655 CPL-M in occlusal (a), buccal (b) and lingual (c) views.

656

657 Figure 4. Comparison of the occlusal morphology of the left $M^{2}$ (IPS102942) of

658 Hispanopithecus cf. laietanus from CPL-M (a) with the $\mathrm{M}^{1}$ and/or $\mathrm{M}^{2}$ of other Vallès-Penedès

659 hominoids: b) left $M^{1}$ (IPS1781) of $H$. laietanus from CCL1; c) right $M^{1}$ (IPS1844, reversed) of 
660

661

662

663

664

665

666

667

668

669

670

671

672

673

674

675

676

677

678

679

680

681

682

683

H. laietanus from CLL1; d) left $\mathrm{M}^{1}$ (IPS1788) of $H$. laietanus from CLL1; e) left $\mathrm{M}^{1}-\mathrm{M}^{2}$ (IPS58338-IPS58338) of $H$. laietanus from CCL1; f) right $\mathrm{M}^{1}-\mathrm{M}^{2}$ (IPS18000.5) of $H$. laietanus from CLL2; g) left M ${ }^{2}$ IPS1794 of $H$. laietanus from CLL1; h) left ?M² (IPS1771) of H. laietanus from CLL1; i) left $M^{1}-M^{2}$ (IPS35026) of Dryopithecus fontani from ACM/C3-Ae; j) left $M^{1}-M^{2}$ (IPS21350, holotype) of Pierolapithecus catalaunicus from ACM/BCV1; k) left $\mathrm{M}^{1}-\mathrm{M}^{2}$ (IPS1798, holotype) of Hispanopithecus crusafonti from CP1; I) left M ${ }^{1}$ (IPS1815) of $H$. crusafonti from CP1; m) left $M^{1}$ (IPS1818) of $H$. crusafonti from CP1; n) left $M^{2}$ (IPS1820 of $H$. crusafonti from $\mathrm{CP} 1 ; 0$ ) right $\mathrm{M}^{3}$ or $\mathrm{M}^{2}$ (IPS1812, reversed) of $H$. crusafonti from $\left.\mathrm{CP} 1 ; \mathrm{p}\right)$ right $\mathrm{M}^{2}$ (IPS1821, reversed) of $H$. crusafonti from CP1; q) left $\mathrm{M}^{1}$ (IPS41712) of Anoiapithecus brevirostris from $\mathrm{ACM} / \mathrm{C} 3-\mathrm{Aj} ; \mathrm{r}$ ) left $\mathrm{M}^{1}-\mathrm{M}^{2}$ (IPS43000, holotype) of $A$. brevirostris from ACM/C3-Aj; s) right $\mathrm{M}^{1}-\mathrm{M}^{2}$ (IPS35027, reversed) of $A$. brevirostris from ACM/C1-E* . Locality abbreviations: $\mathrm{ACM}=$ Abocador de Can Mata (els Hostalets de Pierola); $\mathrm{C} 1=$ Cel $\cdot$ la 1 (ACM sector); C3 = Cel·la 3 (ACM sector); for other abbreviations, see Figure 1 caption.

Figure 5. Bivariate plots of buccolingual breadth (BL, in $\mathrm{mm}$ ) vs. mesiodistal length (MD, in $\mathrm{mm}$ ) of the $\mathrm{M}^{2}$ (IPS102942) of Hispanopithecus cf. laietanus from CPL-M, as compared to the $M^{1}(a)$ and $M^{2}(b)$ of Vallès-Penedès hominoids.

Figure 6. Stratigraphic ranges of the biochronologically most significant rodent species and situation of the Vallès-Penedès localities that have previously yielded fossil remains of Hispanopithecus. Rodent species present at CPL-M are indicated in bold. Dashed lines between rodent species indicate phylogenetic relationships. Local biozonation of the VallèsPenedès Basin is after Casanovas-Vilar et al. (2016b) while Neogene timescale follows Hilgen et al. (2012). In the case of MN (Mammal Neogene) zones, their boundaries are indicated as 
684 defined by selected first appearance events (after Hilgen et al., 2012). The reference sites for 685 MN9 (CLL1) and MN10 (Masía del Barbo, Spain) are denoted with asterisks. Note that CLL1 is 686 herein placed within MN10 when MN zones are defined according to first appearance 687 events. For locality abbreviations, see Figure 1 caption. Other abbreviations: $C$. harten. $=$ 688 Cricetulodon hartenbergeri range subzone; $C . h .-P . h .=$ Cricetulodon hartenbergeri 689 Progonomys hispanicus interval subzone; $C+P=$ Cricetulodon sabadellensis + Progonomys 690 hispanicus concurrent range zone. Rot. montis. = Rotundomys montisrotundi lineage 691 subzone; Rot. bressa. $=$ Rotundomys bressanus lineage subzone. 
Table 1

2 Updated list of the faunal assemblage from Can Pallars i Llobateres (CPL, including those

3 small mammal specimens labelled as CPL3, as well as the large mammal specimens from

4 CPL, CPL-A, CPL-B, CPL-P1, CPL-P3, CPL-P4 and CPL-M).

\begin{tabular}{|c|c|c|}
\hline Order & Family & Taxonomic assignment \\
\hline Testudines & Geoemydidae & Ptychogaster sp. \\
\hline Testudines & Testudinidae & Testudo sp. \\
\hline Testudines & Testudinidae & Titanochelon cf. richardi \\
\hline Squatama & Indet. & Serpentes indet. \\
\hline Primates & Hominidae & Hispanopithecus cf. laietanus \\
\hline Proboscidea & Indet. $^{a}$ & Proboscidea indet. ${ }^{a}$ \\
\hline Artiodactyla & Cervidae & Cervidae indet. \\
\hline Artiodactyla & Bovidae & Miotragocerus aff. pannoniae \\
\hline Perissodactyla & Equidae & Hippotherium (primigenium) cf. catalaunicum ${ }^{b}$ \\
\hline Perissodactyla & Rhinocerotidae & Rhinocerotidae indet. \\
\hline Eulipotyphla & Soricidae & Crusafontina endemica \\
\hline Eulipotyphla & Erinaceidae & Lantanotherium sanmigueli \\
\hline Eulipotyphla & Heterosoricidae & Dinosorex grycivensis \\
\hline Eulipotyphla & Dimylidae & Plesiodimylus chantrei \\
\hline Eulipotyphla & Talpidae & Talpa minuta \\
\hline Lagomorpha & Ochotonidae & Prolagus crusafonti \\
\hline Rodentia & Cricetidae & Cricetulodon sabadellensis \\
\hline Rodentia & Cricetidae & Eumyarion leemanni \\
\hline
\end{tabular}




$\begin{array}{lll}\text { Rodentia } & \text { Cricetidae } & \text { Democricetodon cf. nemoralis } \\ \text { Rodentia } & \text { Cricetidae } & \text { Hispanomys thaleri } \\ \text { Rodentia } & \text { Cricetidae } & \text { Anomalomys gaillardi } \\ \text { Rodentia } & \text { Eomyidae } & \text { Eomyops catalaunicus } \\ \text { Rodentia } & \text { Eomyidae } & \text { Keramidomys pertesunatoi } \\ \text { Rodentia } & \text { Gliridae } & \text { Muscardinus hispanicus } \\ \text { Rodentia } & \text { Gliridae } & \text { Muscardinus vallesiensis } \\ \text { Rodentia } & \text { Gliridae } & \text { Glirulus lissiensis } \\ \text { Rodentia } & \text { Gliridae } & \text { Paraglirulus werenfelsi } \\ \text { Rodentia } & \text { Gliridae } & \text { Myoglis meini } \\ \text { Rodentia } & \text { Sciuridae } & \text { Spermophilinus bredai } \\ \text { Rodentia } & \text { Sciuridae } & \text { Heteroxerus grivensis } \\ \text { Rodentia } & \text { Castoridae } & \text { Euroxenomys minutus }\end{array}$

5

$6 \quad{ }^{a}$ Llenas i Avellaneda (1999) mentioned the recovery of a cervical vertebra of

7 Tetralophodon longirostris, but we were unable to find such a material. All the available

8 proboscidean remains from CPL localities are too fragmentary to enable their identification

9 even at the family rank.

10 bollowing Bernor et al. (1996), we consider Hippotherium (primigenium) as a species

11 complex (as denoted by the name interpolated within parentheses; see ICZN, 1999:Art. 6.2). 



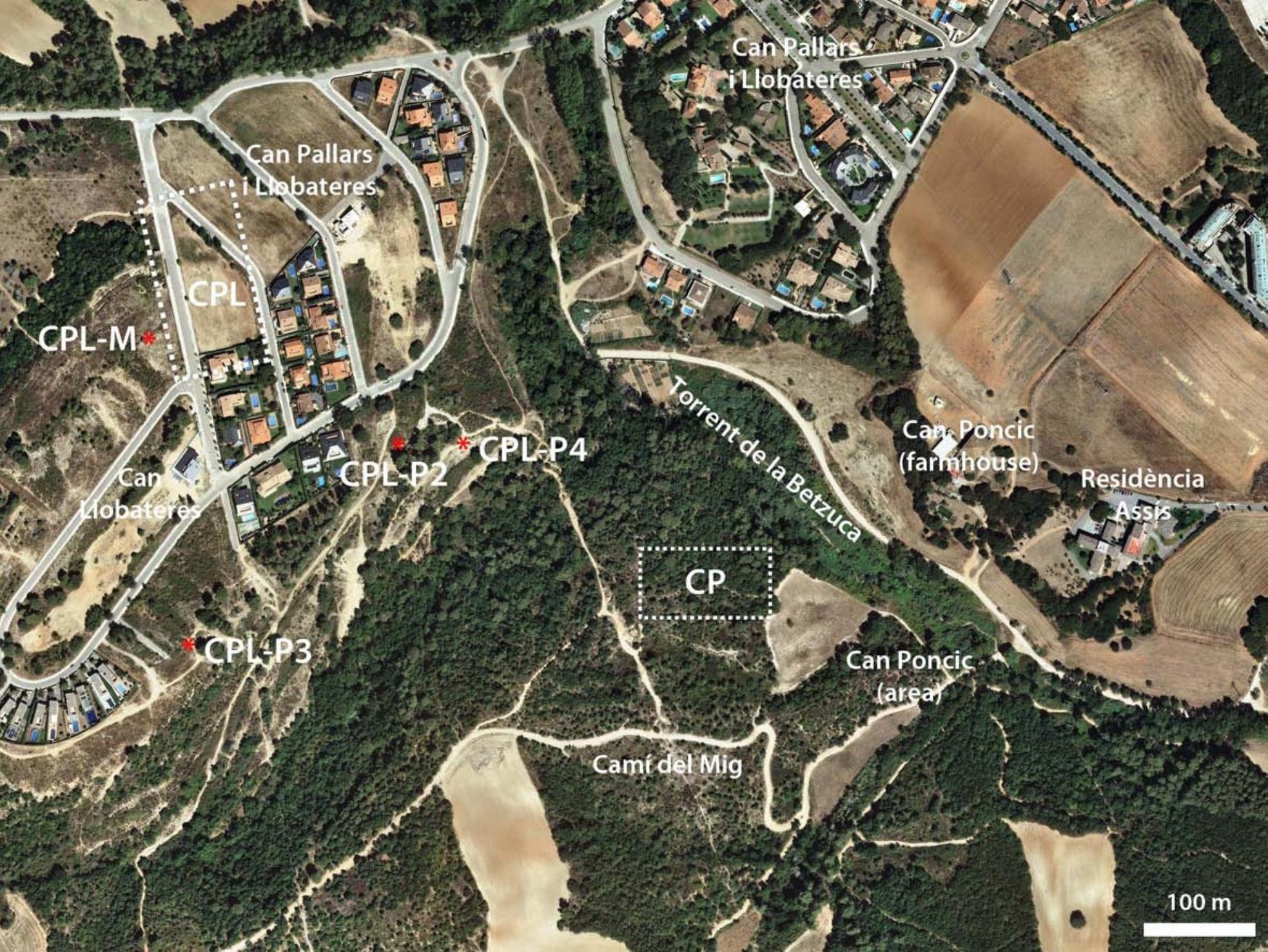




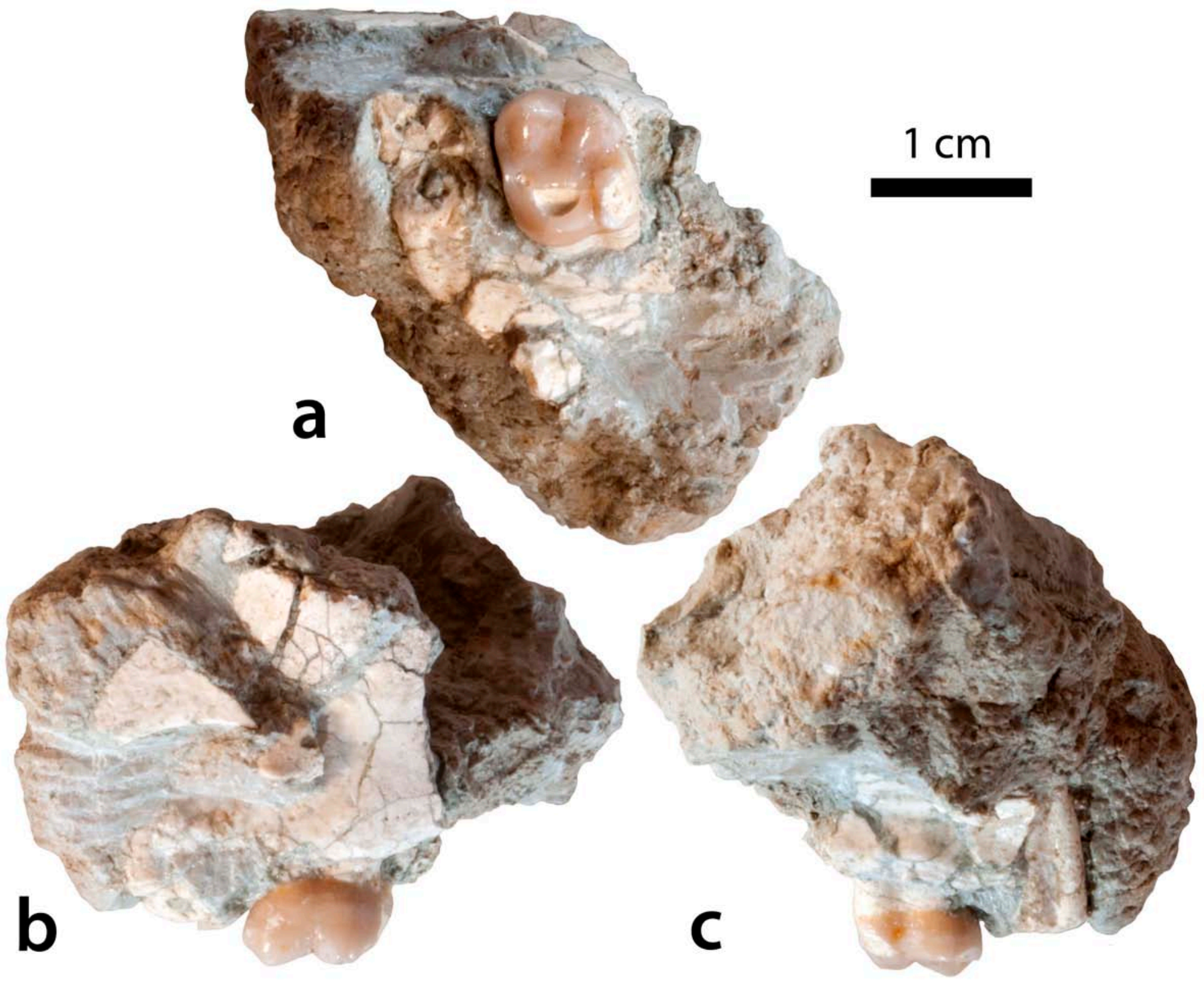


$\square$<smiles></smiles>

$\triangle$

$\triangle$<smiles>[C]1[CH]C=C1</smiles>

x

$\Delta$

9

8

9

10

\section{M1/ length}

b<smiles>CCC[14CH3]</smiles>

$\Delta$

10

*

$\Delta \Delta \Delta x$

$\Delta$

- 듬

$\square$

$\square$

9

899

M2/ length

- A. brevirostris - D. fontani $\triangle$ H. laietanus

A P. catalaunicus $\square H$.crusafonti $\times$ CPL-M 


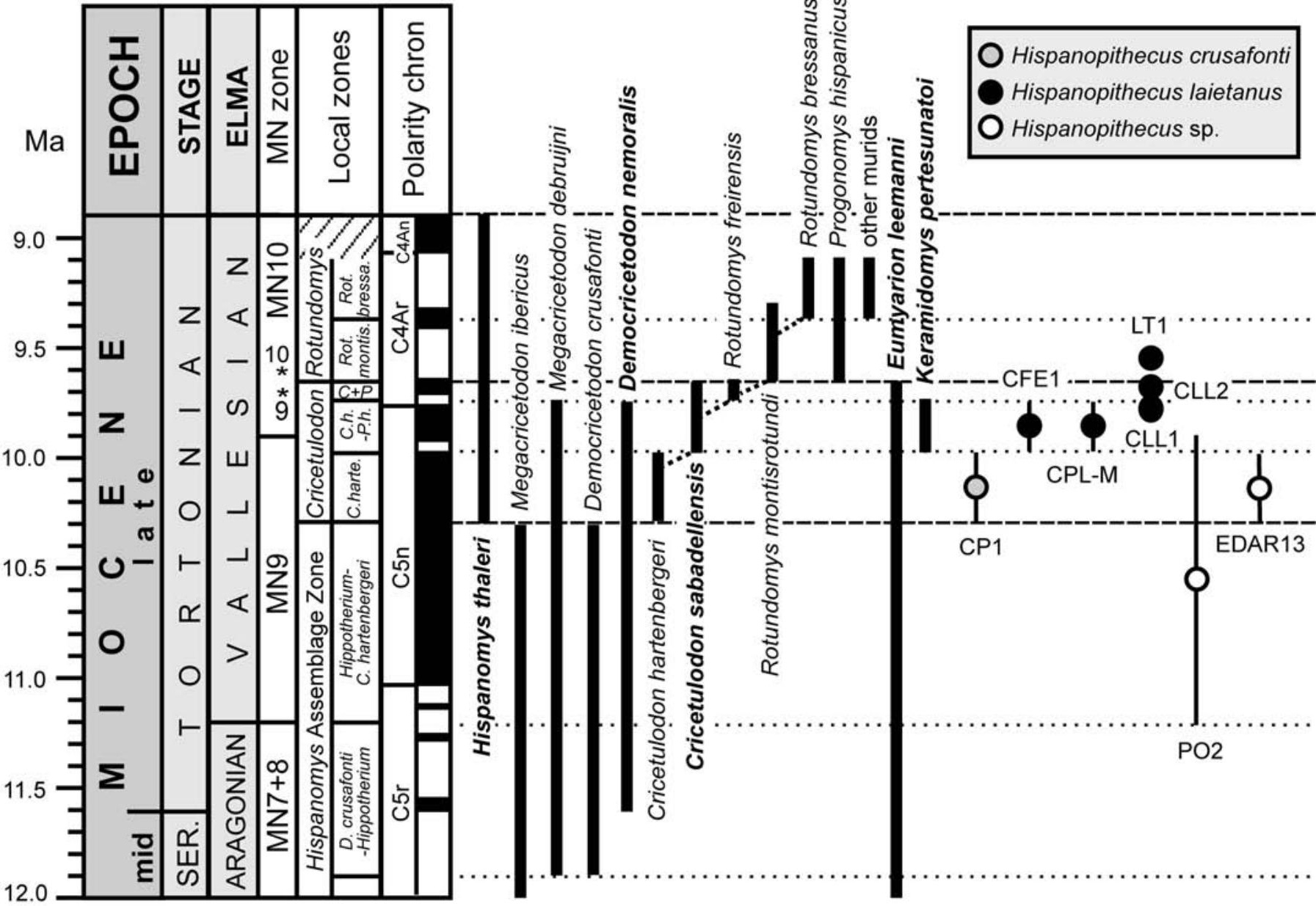




\section{Supplementary Online Material}

Can Pallars i Llobateres: A new hominoid-bearing locality from the late Miocene of the Vallès-Penedès Basin (NE Iberian Peninsula)

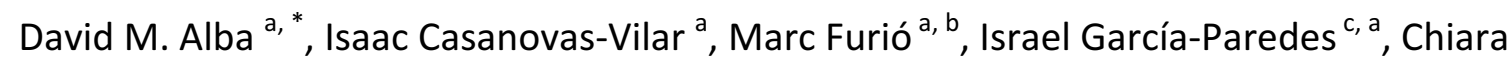

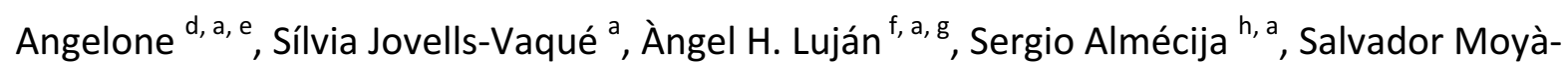
Solà $a, i, j$

${ }^{a}$ Institut Català de Paleontologia Miquel Crusafont, Universitat Autònoma de Barcelona, Edifici ICTA-ICP, c/ Columnes s/n, Campus de la UAB, 08193 Cerdanyola del Vallès, Barcelona, Spain

${ }^{\mathrm{b}}$ Departament de Geologia, Universitat Autònoma de Barcelona, 08193 Bellaterra, Spain

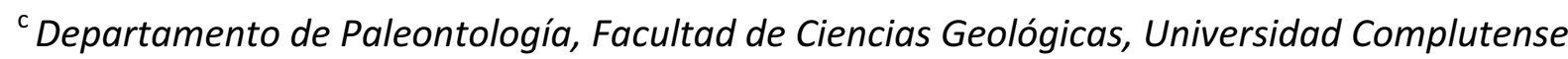
de Madrid, c/ José Antonio Novais 2, 28040 Madrid, Spain

d Dipartimento di Scienze, Università Roma Tre, Largo San Leonardo Murialdo, 1 - 00146, Roma, Italy

e Institute of Vertebrate Paleontology and Paleoanthropology, Chinese Academy of Sciences, Xizhimen Wai Da Jie 142, Beijing 100044, China

${ }^{f}$ Department of Geosciences, University of Fribourg, Chemin de Musée 6, 1700 Fribourg, Switzerland

${ }^{\mathrm{g}}$ Department of Geological Sciences, Faculty of Science, Masaryk University, Kotlářská 2, Brno, 611 37, Czech Republic

${ }^{\mathrm{h}}$ Center for the Advanced Study of Human Paleobiology, Department of Anthropology, The George Washington University, Washington, DC 20052, USA

'Institució Catalana de Recerca i Estudis Avançats (ICREA), Pg. Lluís Companys 23, 08010, Barcelona, Spain

${ }^{j}$ Unitat d'Antropologia Biològica, Departament de Biologia Animal, Biologia Vegetal i Ecologia, Universitat Autònoma de Barcelona, 08193 Cerdanyola del Vallès, Barcelona, Spain

${ }^{*}$ Corresponding author.

E-mail address: david.alba@icp.cat (D.M. Alba). 


\section{SOM S1}

\section{Supplementary materials and methods}

\section{Associated fauna}

The large vertebrate remains from CPL include the following specimens:

- 20 specimens recovered in 1999 from CPL (IPS13989 to IPS13994, IPS13996, IPS103684 to IPS103688, and IPS105907 to IPS105914, of which IPS13993 and IPS105908 come from CPL-B).

- 29 specimens surface-collected, apparently at a later time, from CPL-A (IPS104303 to IPS104322), CPL-B (IPS104294 to IPS104299, and IPS104302) and CPL-P1 (=CPL-C; IPS104299, IPS104300).

- Three specimens most recently recovered in 2017 from CPL-P3 (IPS104355) and CPL-P4 (IPS104348 to IPS104350).

The associated small mammal fauna from CPL includes the following micromammal teeth:

- 279 rodent teeth labeled as coming from CPL (IPS66320 to IPS66598) and 73 from CPL3 (IPS14948, IPS66604 to IPS66638, IPS69519 to IPS69555).

- 30 eulipotyphlan teeth from CPL (IPS65589 to IPS65615, IPS66599 to IPS66601).

- Two lagomorph teeth from CPL3 (IPS66639 and IPS66640).

\section{SOM S2}

\section{Supplementary results}

\section{Associated fauna}

The presence of an indeterminate snake can be ascertained based on a fragmentary vertebra (IPS140320), and the scarce and fragmentary testudine remains allow us to determinate the presence of three different species: a medium-sized tortoise of genus Testudo, based on a couple of peripherals (IPS104299 and IPS104302); a giant tortoise that we assign to Titanochelon cf. richardi, based on another peripheral (IPS104318) and a costal fragment (IPS104348); and a freshwater geoemydid turtle, based on a peripheral (IPS104300) and a costal fragment (IPS104313), the former attributable to genus Ptychogaster.

Owing to the lack of a fossiliferous layer amenable to systematic excavations, large mammals from CPL are insufficiently sampled, so that only a few species can be identified. 
Equids are rather abundantly represented by the three-toed horse Hippotherium (primigenium) cf. catalaunicum, including two lower cheek teeth (IPS13994 and IPS104305; SOM Fig. S1a, b), fragments of metacarpal III (IPS104308 and IPS104315; SOM Fig. S1d), a distal phalanx III (IPS104310), a distal fragment of lateral metapodial (IPS104311), and a calcaneus (IPS104355; SOM Fig. S1c). Some other available remains might belong to the same taxon, but do not preserve enough information so as to be sure. In turn, boselaphin bovids are represented by a small horn core fragment (IPS104349; SOM Fig. S1k), a lumbar vertebral body (IPS13991), a $\mathrm{P}^{3}$ crown fragment (IPS103686), and a hemimandible with $\mathrm{P}_{2}-$ $M_{3}$ (IPS13993; Fig. 6h-j). The dentognathic material, in particular the mandible, is attributable to the antelope Miotragocerus aff. pannoniae sensu Moyà-Solà (1983). Even though the diagnostic metatarsal morphology of this species (Moyà-Solà, 1983; Fuss et al., 2015) cannot be ascertained from this material, several features, such the size of the dentition, rule out an attribution to either Miotragocerus monacensis or Protragocerus chantrei, which are smaller and display shorter and more molarized lower premolars (MoyàSolà, 1983). Following Moyà-Solà (1983), the species assignment is made with open nomenclature, because the available remains correspond to a form smaller than $M$. pannoniae s.s. from similarly-aged localities from the basin, such as Can Llobateres. Due to the scarcity of the material, other large mammals can be only identified to family rank, including: a proboscidean, based on fragments of a long bone (IPS13996), ribs (IPS104316, IPS105913), and indeterminate bones (IPS104314, IPS105914); a rhinocerotid, based on an upper cheek tooth fragment (IPS104304; SOM Fig. S1f), a patella (IPS13990; SOM Fig. S1g), a fragmentary metapodial (IPS105908), and fragments of a long bone (IPS103685) and ribs (IPS104306, IPS105905), among other remains of more dubious taxonomic ascription; and a cervid, based on a distal fragment of humerus (IPS103687; SOM Fig. S1e). Llenas i Avellaneda (1999) reported the presence at CPL of the gomphothere Tetralophodon longirostris, as recorded by a cervical vertebra. However, we were unable to find this specimen among the ICP collections and, therefore, this species is not included on the faunal list reported in Table 1.

In contrast to the scarcity of large mammal remains, micromammals are well represented by a sample of 384 identifiable teeth (SOM Fig. S2). Rodent are represented by 15 out of 21 species, including: five cricetids (Cricetulodon sabadellensis, SOM Fig. S2a, b; Eumyarion leemanni, SOM Fig. S2d; Democricetodon cf. nemoralis, SOM Fig. S2c; Hispanomys thaleri, 
SOM Fig. S2f; and Anomalomys gaillardi, SOM Fig. S2g), two eomyids (Eomyops catalaunicus; and Keramidomys pertesunatoi, SOM Fig. S2e), five glirids (Muscardinus hispanicus, SOM Fig. S2m; Muscardinus vallesiensis, SOM Fig. S2I; Glirulus lissiensis; Paraglirulus werenfelsi, SOM Fig. S2n; and Myoglis meini, SOM Fig. S2k), two sciurids (Spermophilinus bredai, SOM Fig. S2i; and Heteroxerus grivensis, SOM Fig. S2h), and a castorid (Euroxenomys minutus, SOM Fig. S2j). Eulipotyphlans (24\%) includie a soricid (Crusafontina endemica, SOM Fig. S2w, x), an erinaceid (Lantanotherium sanmigueli, SOM Fig. S2r, u), a heterosoricid (Dinosorex grycivensis, SOM Fig. S2s, v), a dimylid (Plesiodimylus chantrei, SOM Fig. S2q, t) and a talpid (Talpa minuta, SOM Fig. S2o, p), whereas lagomorphs (5\%) are represented by the ochotonid Prolagus crusafonti. 

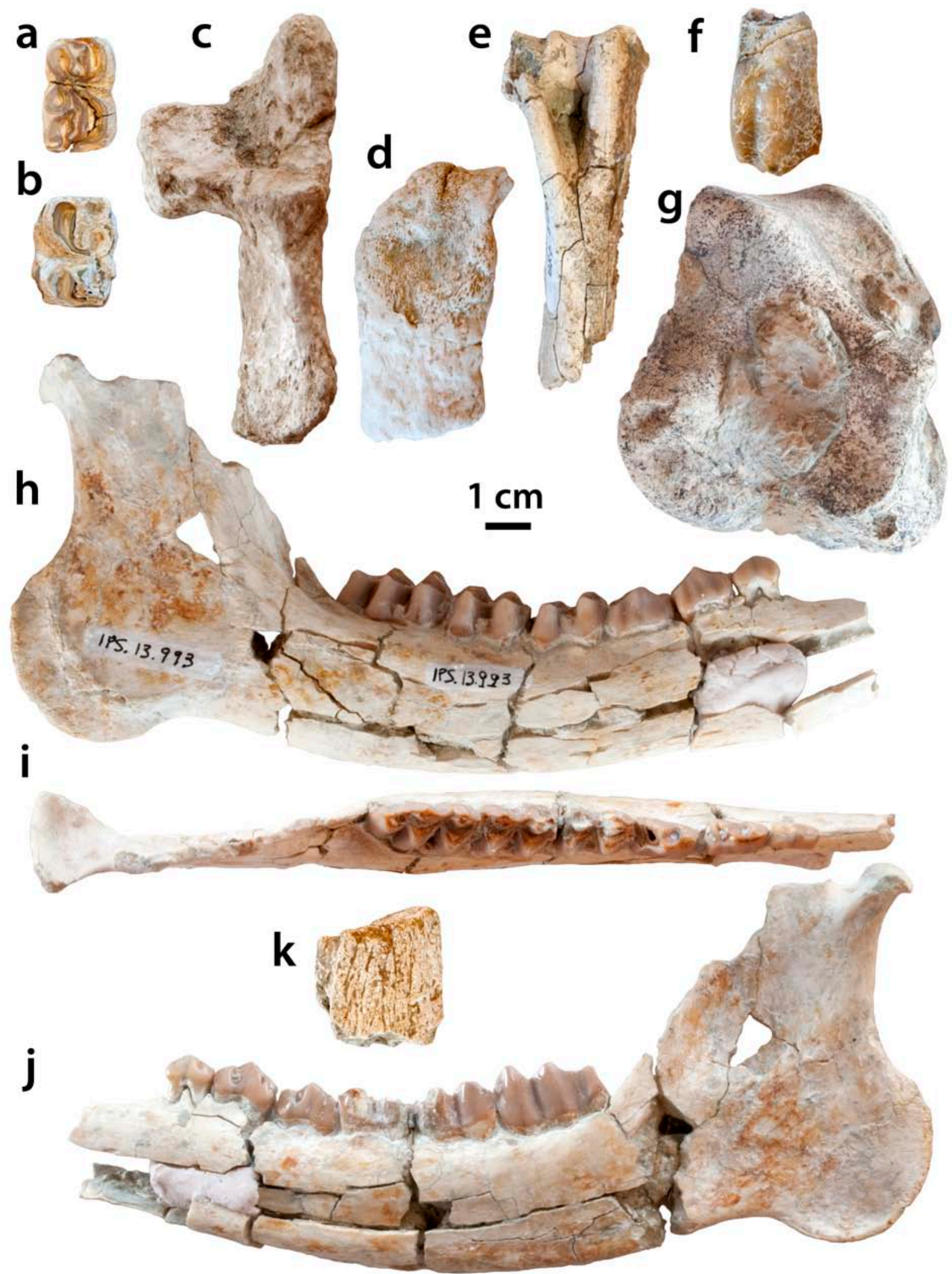

SOM Figure S1. Large mammal remains from CPL: a) right lower cheek tooth $\left(\mathrm{P}_{4}\right.$ or $\mathrm{M}_{1}$; IPS13994) of Hippotherium (primigenium) cf. catalaunicum from CPL, in occlusal view; b) left lower cheek tooth (?P4; IPS103305) of Hi. cf. catalaunicum from CPL-A, in occlusal view; c) right calcaneus (IPS104355) of Hi. cf. catalaunicum from CPL-P3, in dorsal view; d) distal 
fragment of metacarpal III (IPS104315) of Hi. cf. catalaunicum from CPL-A, in anterior view. e) distal fragment of right humerus (IPS103687) of Cervidae indet. from CPL, in posterior view; f) fragment of upper cheek tooth (IPS104304) of Rhinocerotidae indet from CPL-A, in buccal view; g) patella (IPS13990) of Rhinocerotidae indet. from CPL, in posterior view; $\mathrm{h}-\mathrm{j}$ ) right hemimandible with $\mathrm{P}_{2}-\mathrm{M}_{3}$ (IPS13993) of Miotragocerus aff. pannoniae from CPL- $\mathrm{B}$, in buccal (h), occlusal (i) and lingual (j) views; k) horn core fragment (IPS104349) of Boselaphini indet. from CPL-P4. 


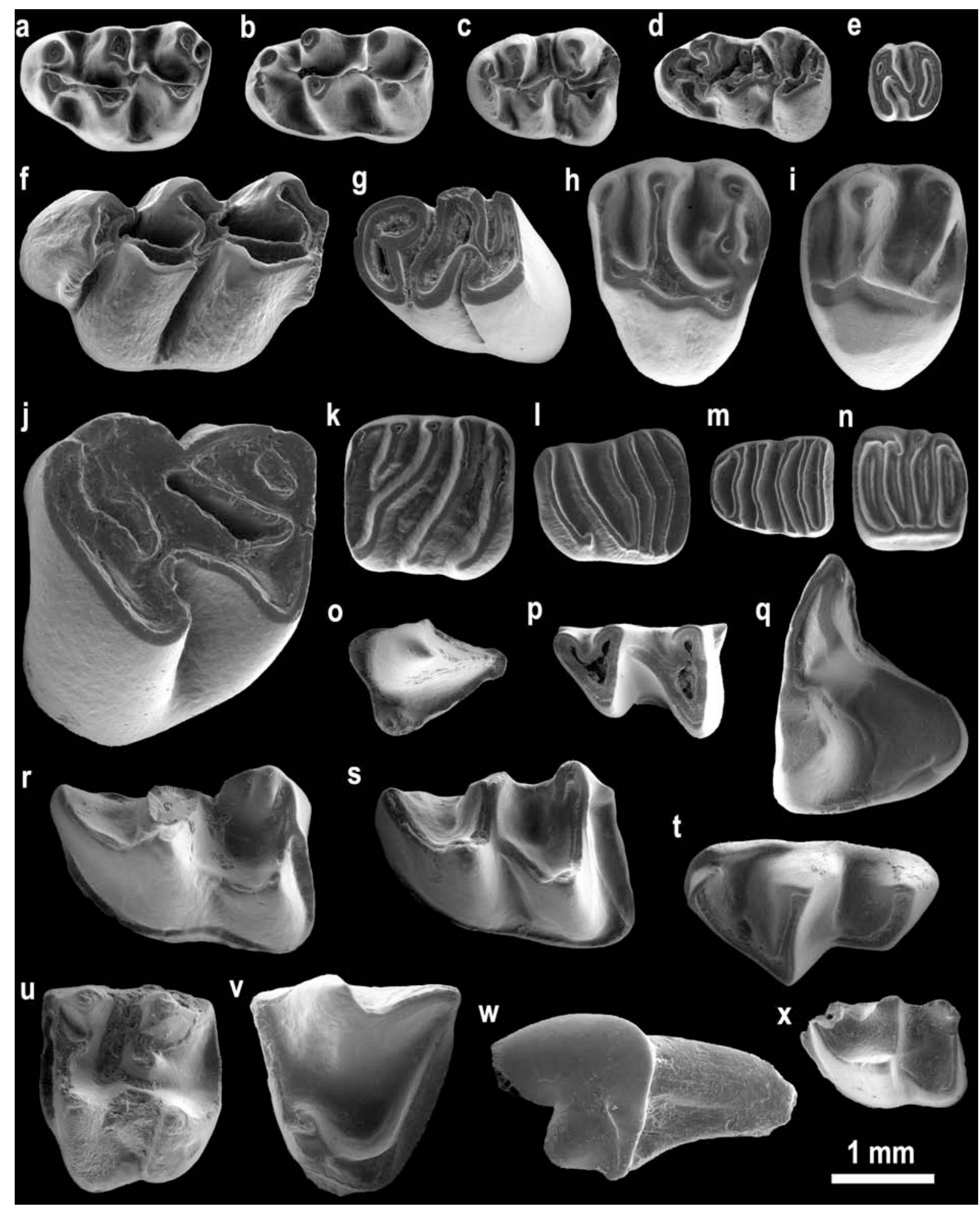

SOM Figure S2. SEM micrographs of selected small mammal remains from CPL: a) left $M^{1}$ (IPS66333) of Cricetulodon sabadellensis; b) right M (IPS66470, reversed) of $C$. sabadellensis; c) left $\mathrm{M}_{1}$ (IPS66594) of Democricetodon cf. nemoralis; d) right $\mathrm{M}_{1}$ (IPS66574, reversed) of Eumyarion leemanni; e) left $\mathrm{M}_{1}$ or $\mathrm{M}_{2}$ (IPS66595) of Keramidomys pertesunato; f) left $\mathrm{M}^{1}$ (IPS66542) of Hispanomys thaleri; g) left $\mathrm{M}_{1}$ (IPS66607) of Anomalomys gaillardi; $\mathrm{h}$ ) left $\mathrm{M}^{1}$ or $\mathrm{M}^{2}$ (IPS66611) of Heteroxerus grivensis; i) left $\mathrm{M}^{1}$ or $\mathrm{M}^{2}$ (IPS66622) of 
Spermophilinus bredai; j) left $\mathrm{M}^{1}$ or $\mathrm{M}^{2}$ (IPS66610) of Euroxenomys minutus; $\mathrm{k}$ ) right $\mathrm{M}_{1}$ (IPS69520, reversed) of Myoglis meini; I) left $\mathrm{M}^{1}$ (IPS69550) of Muscardinus vallesiensis; $\mathrm{m}$ ) left $\mathrm{M}_{1}$ (IPS69542) of Muscardinus hispanicus; $\mathrm{n}$ ) left $\mathrm{M}^{2}$ (IPS69525) of Paraglirulus werenfelsi; o) left $\mathrm{P}^{4}$ (IPS65590) of Talpa minuta; $\mathrm{p}$ ) left $\mathrm{M}_{1}$ (IPS65614) of $T$. minuta; q) right $\mathrm{M}^{2}$ (IPS65606, reversed) of Plesiodimylus chantrei; $r$ ) left $\mathrm{M}_{1}$ (IPS65612) of Lantanotherium sanmigueli; s) left $\mathrm{M}_{1}$ (IPS65610) of Dinosorex grycivensis; $\mathrm{t}$ ) left $\mathrm{M}_{2}$ (IPS65615) of PI. chantrei; u) left $\mathrm{M}^{2}$ (IPS65594) of L. sanmigueli; v) right $\mathrm{P}^{4}$ (IPS65604, reversed) of $D$. grycivensis; w) left I ${ }^{1}$ (IPS65593) of Crusafontina endemica; $\mathrm{x}$ ) right $\mathrm{M}_{2}$ (IPS65597, reversed) of Cr. endemica. 